\title{
Amitraz: pharmacological and toxicological aspects in animals
}

\author{
[Amitraz: aspectos farmacológicos e toxicológicos em animais]
}

\section{"Revisão/Review"}

\section{Mariana Lumack do Monte Barretto, Amanda de Deus Ferreira, Ingrid Cavalcanti Pascoal, Melina Barreto Gomes da Silva, Sandra Maria de Torres, Marcus Vinícius Dias Falcão, Andrea Alice da Fonseca Oliveira*}

Departamento de Medicina Veterinária, Universidade Federal Rural de Pernambuco, Recife-PE, Brasil.

*Autor para correspondência/Corresponding author: E-mail: andreaafo@ hotmail.com

\begin{abstract}
Infestations by ectoparasites are one of the greatest problems in the veterinary practice, due to a large drop in performance in cattle herds and other farm animals, generating great economical losses; for pets, besides the low quality of life and disruption of homeostasis, ectoparasites represent a risk for transmission of zoonotic diseases. The formamidines emerge as a very large group of ectoparasiticides, which its main representative, amitraz, is the only one approved for animal use. Amitraz is indicated for animal use against mites, lice, and ticks for cattle, swine, and sheep. For dogs, it is used against ticks and mites. However, due to a lack of proper orientation and information, reports of accidental intoxications by amitraz, in both animals and humans, are not unusual in the literature. Amitraz intoxication has been reported in dogs, and the clinical signs are evidenced in the nervous, digestive, cardiovascular, and urinary systems and include sedation, bradycardia, bradyarrhythmias, hypotension, bradypnea, transitory hyperglycemia, mydryasis, and hypothermia, cats being more sensitive than dogs regarding these last signs. To detect amitraz and its main metabolites, there are many standardized methodologies. This review describes the pharmacokinetics, pharmacodinamics, indications, toxicological and pathological effects of amitraz, as well as the intoxication treatment and the aspects related to its detection in biological matrices.
\end{abstract}

Keywords: Formamidines; poisoning; dog; pathology.

\section{Resumo}

As infestações por ectoparasitas representam um dos maiores problemas na rotina da clínica médica veterinária, com impactos relacionados à queda no rendimento de animais de produção, gerando graves perdas econômicas; para os animais de companhia, além da baixa qualidade de vida e do desequilíbrio da homeostase, ectoparasitas representam um risco para a transmissão de zoonoses. As formamidinas surgem como um grupo de ectoparasiticidas cujo representante principal, o amitraz, é o único aprovado para uso animal. O amitraz é indicado para uso animal contra ácaros, piolhos e carrapatos de bovinos, suínos e ovinos. Para cães, preconizase seu uso contra carrapatos e ácaros. Entretanto, devido à ausência de orientação adequada, os casos de intoxicações acidentais por amitraz, tanto em animais como em humanos, são frequentemente relatados. A intoxicação por amitraz tem sido relatada em cães, e os sinais clínicos são evidenciados em sistemas nervoso, digestivo, cardiovascular e urinário e incluem sedação, bradicardia, bradiarritmias, hipotensão, bradpneia, hiperglicemia transitória, midríase e hipotermia, sendo os gatos mais sensíveis do que os cães em relação a estes últimos sinais. Para detectar amitraz e seus principais metabólitos, existem muitas metodologias padronizadas. Esta revisão descreve a farmacocinética, farmacodinâmica, indicações de uso, efeitos toxicológicos e patológicos, além do tratamento da intoxicação e dos aspectos analíticos relacionados à sua detecção em matrizes biológicas.

Palavras-chave: Formamidinas; envenenamento; cão; patologia. 


\section{Introduction}

Parasitism is one of the greatest problems in veterinary medicine, especially in hot and wet tropical countries (Sartor and Santarém, 2006). Ectoparasitism occupy a prominent place among the parasitic diseases that affect farm animals, raising direct and indirect costs, due to the drop of the animals' yield and the need for a sanitary control (Fonseca et al., 2009). Meanwhile, for companion animals, the problem is also severe, since it directly compromises their welfare, besides representing a risk to human health, due to zoonotic transmission (Dantas-Torres and Otranto, 2014).

In the 19th century, arsenical solutions were the first substances used for control of ectoparasites, and were introduced in Brazil by 1900. After the discovery of resistance mechanisms to ectoparasiticides, other compounds were developed, such as dichlorodiphenyltrichloroethane (DDT), hexachlorocyclohexane (HCH), toxaphene e dieldrin. From 1941, new acaricidal compounds have been synthesized, such as organophosphates, organochlorides, carbamates, and pyrethroids (Sartor and Santarém, 2006).

Chlordimeform, the first formamidine, appeared in 1963 (Hollingworth, 1976), followed by other drugs such as amitraz, or N'- $(2,4-$ dimethylphenyl)-N-[(2,4-imethylphenyl) iminomethyl] -N-methylmehtanimidamide, of molecular formula C19H23N3 (Pubchem, 2015), in England in 1969 (Hollingworth, 1976). This is the most used active substance among the formamidines, including in Brazil, because it is the only one approved for animal use (Sakate et al., 1992; Sartor and Santarém, 2006).

This review describes the pharmacokinetics, pharmacodinamics, indications, toxicological and pathological effects of amitraz, as well as the intoxication treatment and the aspects related to its detection in biological matrices.

\section{Pharmacokinetics and pharmacodinamics}

Amitraz is quickly hydrolyzed in an acid environment when it is orally administrated, due to its instability in this environment (Sartor and Santarém, 2006). The hydrolysis in a low pH generates the compound 2,4-dimethylphenyl formamide, which is stable in an acid environment. This substance can still be hydrolyzed, generating 2,4-dimethylaniline (Pierpoint et al., 1997). Absorption is effective through the skin, which may be major or minor depending on its integrity, the occurrence of injuries, and inflammation. After reaching the blood stream, the drug reaches the highest plasmatic level in up to two hours (Dallegrave and Sebben, 2008). The biotransformation occurs in the liver, generating the active metabolite BTS 27271, the most important pharmacologically (Santarém et al., 2008), because it acts directly in the regulation of the insulin and glucagon secretion by binding to the $\alpha 2 \mathrm{~A}$ and $\alpha 2 \mathrm{D}$-adrenergic receptors, inhibiting insulin and stimulating glucagon secretion, resulting in hyperglycemia (Abu-Basha et al., 1999). Metabolites are excreted in bile and urine (Sartor and Santarém, 2006; Santarém et al., 2008).

In insects, formamidines such as chlordimeform and amitraz operate its toxic effects by interacting with octopaminergic receptors in the central nervous system (Evans and Gee, 1980; Chen et al., 2007). The mechanisms by which the deleterious effects of amitraz in mammals are determined are based on its agonistic action on $\alpha 2$ adrenergic receptors and inhibitory action over the monoamine oxidase (MAO), but there are reports of various action pathways, such as: H1 histamine receptor inhibition, prostaglandin synthase inhibition, adenylyl cyclase inhibition, voltagegated calcium channels activation, reactive oxygen species generation, cell death induction and endocrine disruptions. Amitraz is also related to the emergence of neurotoxic effects and modifications in the reproductive sphere in rats (Del Pino et al., 2015).

\section{Indications and contraindications}

Amitraz is indicated for animal use against mites, lice and ticks for cattle, swine and sheep. For dogs, it is used against ticks and mite (Sartor and Santarém, 2006). It was reported as the drug of choice in the treatment of localized and generalized demodicosis in dogs (Folz et al., 1984). Along with macrocyclic lactones such as milbemycin oxime, ivermectin, moxidectin, and doramectin, amitraz is still recommended for the treatment of generalized canine demodicosis, although it is not very efficient in adult-onset demodicosis cases (Mueller, 2004; Mueller et al., 2012). Cowan and Campbell (1988) and Chesney (1989) also reported the use of amitraz in the treatment of demodicosis in cats. Gunaratnam et al. (1983) evaluated amitraz toxicity in cats, and concluded that low concentrations, around $0,0125 \%$ are capable of generating moderate toxic effects, especially 
anorexia. The toxic effects are even more evident in cats, due to their licking habit, resulting in a higher intake of the product. However, it is possible to use amitraz topically in healthy cats, respecting the appropriate contraindications common to the other species, which is to avoid the use in diabetic, hypothermic, and cardiac patients (Andrade et al., 2007).

Amitraz is contraindicated in horses due to the risk of hypomotility and intestinal atony, leading to severe intestinal impaction (Duarte et al., 2003; Santarém et al., 2008). Duarte et al. (2003) observed, besides the intestinal symptoms, the occurrence of neurologic signs as drowsiness, decreased cranial nerve reflexes and ataxia in horses submitted to the experimental use of amitraz. This substance is contraindicated for patients with extended skin injuries, which could lead to an over absorption, favoring intoxication (Santarém et al., 2008).

\section{Toxicological and pathological aspects of amitraz poisoning in animals}

In Brazil, data provided by the Sistema Nacional de Informações Tóxico-Farmacológicas (SINITOX) showed that in the year of 2013, 42128 cases of human intoxications and 255 cases of animal intoxications of any etiologies were registered (Fiocruz, 2013a). Veterinary products were responsible for the notification of 307 cases of human intoxications and 7 cases of animal intoxications in the same year (Fiocruz, 2013b). However, these numbers may be even higher, due to a high rate of underreported cases by the Centro de Informação e Assistência Toxicológica (CIAT) of each Brazilian state (Fiocruz, 2013).

Several studies about amitraz acute toxicity were previously conducted in many species, regarding the median lethal dose 50 (LD50) (Table $1)$.

Table 1. Oral $\mathrm{LD}_{50}$ values for dog, mouse, rat and chick.

\begin{tabular}{ccc}
\hline Species & LD $_{\mathbf{5 0}}$ & Authors \\
\hline Mouse & $>1600 \mathrm{mg} / \mathrm{kg}$ & Al-Thani et al. (2003) \\
Rat & $515-938 \mathrm{mg} / \mathrm{kg}$ & Dallegrave and Sebben (2008) \\
Dog & $100 \mathrm{mg} / \mathrm{kg}$. Intoxication signs at doses of $20 \mathrm{mg} / \mathrm{kg}$. & Dallegrave and Sebben (2008) \\
Chick & $53,05 \mathrm{mg} / \mathrm{kg}$ & Al-Hammdani and Al-Baggou (2014) \\
\hline
\end{tabular}

Amitraz intoxication has been reported in dogs, and the clinical signs are evidenced in nervous, digestive, cardiovascular, and urinary systems (Oglesby et al., 2006) and include sedation, bradycardia, bradyarrhythmias, hypotension, bradypnea, transitory hyperglycemia, mydryasis, and hypothermia, cats being more sensitive than dogs regarding these last signs (Andrade et al, 2008). Emesis, diarrhea, abdominal pain, and intestinal hypomotility are observed in the digestive system. In the urinary system, there is polyuria (Xavier et al., 2008). It is the stimulation of $\alpha 2$-adrenergic receptors that generates the main signs of amitraz poisoning, such as loss of consciousness, breathing depression, seizures, bradycardia, hypotension, and hypothermia (Proudfoot, 2003).

Electrocardiographic changes have been reported after the experimental use of amitraz in healthy dogs. Right after the intravenous administration of amitraz, there was a reduction in the duration of the $\mathrm{P}$ wave and an increase in the length of QT, PT, and RR intervals, but without changes in the QRS complex and in the amplitude of the $\mathrm{R}$ wave, besides a marked bradycardia. These results are consistent with the $\alpha 2$-agonistic action of amitraz, but there were no sinoatrial blocks, as expected (Farias et al., 2005). In a different study, the cardiovascular and respiratory effects after the intravenous administration of amitraz in dogs, in increasing doses of 1, 2 and 5 $\mathrm{mg} / \mathrm{kg}$ were reported. Thus, an increase in blood pressure during one hour and an initial bradycardia were observed, which returned to normal levels in a dose-dependent way. The tidal volume, the respiratory rate, and the respiratory volume per minute presented an initial drop. On the other hand, hyperventilation was observed after the use of high doses of amitraz (Cullen and Reynoldson, 1987).

Accidental poisoning with amitraz was described in two Simmental cows. The animals received accidental intramuscular injections of amitraz, and among the clinical signs, anorexia, depression, reduced rumen motility, congestion of episcleral vessels, light bloat, and loss of pupillary reflex were observed. Heart and respiratory rates and rectal temperature remained unchanged. The poisoning was treated with yohimbine, and after 24 
hours, the animals were clinically stable (Kizil et al., 2008).

In a study on the acute intoxication by amitraz in mice, the histopathological findings after the oral administration of growing doses of both the technical and commercial formulations of amitraz in two distinct groups were analyzed. It was observed that the groups that received doses equal or higher than $1500 \mathrm{mg} / \mathrm{kg}$ of the technical formulation presented degenerative hepatic changes. At a dose of $1500 \mathrm{mg} / \mathrm{kg}$, there was hydropic degeneration; at $1800 \mathrm{mg} / \mathrm{kg}$, both hidropic and fatty degeneration; at $2200 \mathrm{mg} / \mathrm{kg}$ and $2500 \mathrm{mg} / \mathrm{kg}$, there were severe degenerative injuries. Similar injuries were seen in animals who received the commercial formulation, but at a dose equal or higher than $250 \mathrm{mg} / \mathrm{kg}$. This kind of formulation also led to the development of epithelial cell necrosis at a dose of $500 \mathrm{mg} / \mathrm{kg}$, and at the doses of $750 \mathrm{mg} / \mathrm{kg}$ and $1000 \mathrm{mg} / \mathrm{kg}$, tubular epithelial cells necrosis was observed (Filazi et al., 2004).

Omoja et al. (2016a) evaluated the hepatic and renal effects of the subchronical administration of a commercial formulation of amitraz $12.5 \%$ in albinoWistar rats for 84 days. Four experimental groups were designated, whose doses corresponded to $10 \mathrm{mg} / \mathrm{kg}, 2 \mathrm{mg} / \mathrm{kg}$, and $0.4 \mathrm{mg} / \mathrm{kg}$, and the fourth group received $10 \mathrm{ml} / \mathrm{kg}$ of water, by oral route. The group treated with $10 \mathrm{mg} / \mathrm{kg}$ presented moderate hepatic vacuolar degeneration of periportal hepatocytes and mild to moderate generalized tubular degeneration in kidneys, affecting pars recta, proximal convoluted tubules, and collecting tubules. The remaining groups didn't show any significant changes. This way, it can be inferred that the chronic use of amitraz in high doses may provoke severe damages to the hepatic and renal tissues. Through the same protocol, Omoja et al. (2017) also observed that rats exposed to a $10 \mathrm{mg} / \mathrm{kg}$ dose, given daily by oral route may present regenerative anemia by the 30th day of treatment, analyzed by the mean levels of packed cell volume, red blood cell and total white blood cell counts, and hemoglobin.

The amitraz toxicity related to the reproductive sphere was evaluated in rats, which received orally growing doses of the drug $(40,120$, and $360 \mathrm{ppm}$ ). Significant changes were observed only after a $360 \mathrm{ppm}$ dose, in which there was a decrease in the seminal vesicles' weight, decrease of sperm motility, fewer living offspring, and increased losses after deployment (Lim et al., 2010). Omoja et al. (2016b) also investigated the reproductive effects in male Wistar rats subchronically exposed to growing doses of amitraz by oral route, and concluded that there is a dosedependent influence of amitraz over testosterone production and sperm reserve, besides the appearance of testicular degeneration in the group treated with a dose of $10 \mathrm{mg} / \mathrm{kg} /$ day.

In a case report of accidental poisoning with amitraz in a dog, which resulted in the death of the animal, the main post mortem findings were pulmonary edema, hemorrhagic gastroenteritis, cardiac, pulmonary, renal, hepatic and splenic hemorrhages, and also brain congestion and edema (Andrade et al., 2004).

In a second case of accidental poisoning in a dog by ingestion of a bait containing amitraz, the necropsy revealed severe ventral subcutaneous edema and moderate serosanguineous ascites, diffuse hemorrhage on the left kidney and partial on the right kidney. Histopathological analysis of the kidney showed severe diffuse cortical hemorrhage, obliterating the interstitial tissue; glomerular and tubular necroses were also evident, besides a neutrophilic infiltration due to the necrosis. The cells presented intense eosinophilia, unbundling of the basal membrane, karyolysis and pyknotic nuclei. Yet, there were certain multifocal deposits of fibrin, severe cortical vessel congestion and moderate congestion in the medulla. Histopathological analysis of the liver revealed severe congestion and sinusoidal enlargement, hepatocyte atrophy, multifocal fatty degeneration, and some necrotic areas (Oglesby et al., 2006).

\section{Treatment}

The reversion of amitraz poisoning in animals is based on the supportive therapy, gastrointestinal decontamination, and the use of a2-adrenoceptor antagonists such as yohimbine (Andrade et al., 2005; Smerdel et al., 2008) and atipamezole (Hugnet et al., 1996; Andrade et al., 2005). Yohimbine is reported for reversing the alterations caused by amitraz administration in high concentrations, such as hypotension, bradycardia, emesis, salivation, mydriasis, moderate sedation, hyperglycemia, and in some cases, synusal arrhythmia (Smerdel et al., 2008). Atipamezole is a potent selective $\alpha 2$-adrenoceptor antagonist, not interacting with other receptors. It is a great antagonist of xylazine and medetomidine, 
drugs known for their agonistic activity on $\alpha 2$ adrenergic receptors, as is amitraz (Cardoso et al., 2011).

\section{Laboratory analyses}

To detect amitraz and its main metabolites, there are many standardized methodologies. According to Hugnet et al. (1996), it is possible to evaluate the plasmatic toxicokinetics of amitraz in dogs by high-performance thin layer chromatography (HPTLC), an easily reproducible technique. Zanella et al. (1999) quantified amitraz in ectoparasiticide bath solutions used in cattle by HPLC-UV technique. This technique was effective for detection of amitraz in the samples, and has allowed quantifying the active ingredient without any interference from foreign substances. Saito et al. (2008) validated a methodology for detection of amitraz and its metabolites in human serum by liquid chromatography-mass spectrometry (LCMS), using monolithic silica column with acetonitrile. Marafon et al. (2010) seek to standardize and validate the technique of gas chromatography with thermionic sensitive detection (GC-TSD), and thus determine the amitraz concentration in the blood of cats experimentally submitted to ectoparasiticide dipping baths of amitraz $0.4 \%$. This technique comes in use to determine the pharmacokinectics of amitraz in cats. GUO et al. (2014) developped an analitical methodology for amitraz and its metabolites N-[2,4-(dimethylphenyl) -N'-methylformamidine, 2,4-dimethylformamidine e 2,4dimethylaniline in human blood samples, by solid phase extraction (SPE) and liquid chromatographytandem mass spectrometry. This methodology was effective, sensitive, selective, and reproducible to detect and analyze amitraz and its metabolites in blood samples.

\section{Conclusion}

Due to its high efficacy against a wide range of ectoparasites in livestock and pet animals, amitraz is a common product in veterinary practices and homes. As a result, both accidental and intentional poisoning in animals and humans is currently underreported and requires wider attention from both medical and veterinary practitioners.

\section{Acknowledgments}

The first author would like to thank the Programa Institucional de Bolsas de Iniciação
Científica (CNPq/PIBIC/UFRPE). We also thank Professor George Chaves Jimenez for the Consulting.

\section{References}

Abu-Basha, E.A; Yibchok-Anun, S.; Hopper, D.L.; Hsu, W.H. Effects of the pesticide amitraz and its metabolite BTS 27271 on insulin and glucagon secretion from the perfused rat pancreas: involvement of $\alpha 2 \mathrm{D}$-adrenergic receptors. Metabolism, 48(11): 1461-1469, 1999.

Al-Hammdani, Y.A.; Al-Baggou, B.K. Study of acute toxicosis and biochemical changes induced by amitraz in chicks. Iraqi Journal of Veterinary Sciences, 28(2): 143-148, 2014.

Al-Thani, R.K.; Al-Thani, A.S.; Elbetieha, A.; Darmani, $\mathrm{H}$. Assessment of reproductive and fertility effects of amitraz pesticide in male mice. Toxicology Letters, 138: 253-260, 2003.

Andrade, S.F.; Sanches, O.; Tostes, R.A. Relato de cinco casos de intoxicação por amitraz em cães e gatos. Clínica Veterinária, 9(53): 38 42, 2004.

Andrade, S.F.; Sakate, M.; Crocci, A.J. Effects of yohimbine and atipamezole on plasmatic glucose concentration and blood gas analysis in dogs intoxicated with Triatox $^{\circledR}$. Ars Veterinaria, 21:121-128, 2005.

Andrade, S.F.; Laposy, C.B.; Cardoso, C.S.; Sakamoto, K.P.; Motta, Y.P. Uso tópico do amitraz em concentração terapêutica em gatos. Ciência Rural, 37(4): 1027-1032, 2007.

Andrade, S.F.; Laposy, C.B.; Rodrigues, L.T.; Marcicano, J.; Andrade Jr, C.V.; Appel, T.L. Estudo comparativo da intoxicação experimental por amitraz em cães e gatos. Brazilian Journal of Veterinary Research and Animal Science, 45(1): 17-23, 2008.

Brogdon, W.G.; Mcallister, J.C. Insecticide resistance and vector control. Emerging Infectious Diseases, 4(4): 605-613, 1998.

Cardoso, C.S.; Jorge, E.B.; Santos, A.B.; Smerdel, J.P.S.; Gabriel Filho, L.R.A.; Andrade, S.F. Comparative study of the effects of medetomidine and xylazine in cats and reversal with atipamezole. Colloquium Agrariae, 7(1): 52-60, 2011.

Chen, A.C.; He, H.; Davey, R.B. Mutations in a putative octopamine receptor gene in amitraz- 
resistant cattle ticks. Veterinary Parasitology, 148: 379-383, 2007.

Chesney, C.J. Demodicosis in the cat. Journal of Small Animal Practice, 30(12): 689-695, 1989.

Cowan, L.A.; Campbell, K. Generalized demodicosis in a cat responsive to amitraz. Journal of American Veterinary Medical Association, 192(10): 1442-1444, 1988.

Cullen, L.K.; Reynoldson, J.A. Cardiovascular and respiratory effects of the acaricide amitraz. Journal of Veterinary Pharmacology and Therapeutics, 10(2): 134-143, 1987.

Dallegrave, E.; Sebben, V.C. Toxicologia clínica: aspectos téorico-práticos. In: Gonzáles, F.H.D.; Silva, S.C. Patologia clínica veterinária: texto introdutório. Porto Alegre: Universidade Federal do Rio Grande do Sul, 2008, p.206-289.

Dantas-Torres, F.; Otranto, D. Cães, gatos, parasitos e humanos no Brasil: abrindo a caixa preta. Parasites and Vectors, 7(22):1-48, 2014.

Del Pino, J.; Moyano-Cires, P.V.; Anadon, M.J.; Diaz, M.J.; Lobo, M.; Capo, M.A.; Frejo, M.T. Molecular Mechanisms of amitraz mammalian toxicity: a comprehensive review of existing data. Chemical Research in Toxicology, 28(6): 1073-1094, 2015.

Duarte, M.D.; Peixoto, P.V.; Bezerra Junior, P.S.; Oliveira, K.D.; Loretti, A.P.; Tokarnia, C.H. Intoxicações natural e experimental por amitraz em equídeos: aspectos clínicos. Pesquisa Veterinária Brasileira, 23(3): 105118, 2003.

Evans, P.D.; Gee, J.D. Action of formamidine pesticides on octopamine receptors. Nature, 287: 60-62, 1980.

Farias, A.; Valadão, C.A.A.; Oleskovicz, N. Estudo eletrocardiográfico em cães submetidos à aplicação intravenosa de amitraz. Ars Veterinaria, 21(4): 109-115, 2005.

Filazi, A.; Güvenç, T.; Kum, C.; Sekk, S. Pathological findings in acute amitraz intoxication in mice. Turkish Journal of Veterinary and Animal Sciences, 28(5): 873-878, 2004.

FIOCRUZ. Fundação Oswaldo Cruz. Sistema Nacional de Informações TóxicoFarmacológicas. Dados de intoxicação. Brasil, 2013. Available from: $<$ http://sinitox.icict.fiocruz.br/dadosnacionais>. Updated 2017 March 18.
FIOCRUZ. Fundação Oswaldo Cruz. Sistema Nacional de Informações TóxicoFarmacológicas. Tabela 1. Casos registrados de Intoxicação Humana, de Intoxicação Animal e de Solicitação de Informação por Região e por Centro. Brasil, 2013a. Available from: http://sinitox.icict.fiocruz.br/sites/sinitox.icict .fiocruz.br/files//Tabela1_2013.pdf. Updated 2017 March 18, 2017.

FIOCRUZ. Fundação Oswaldo Cruz. Sistema Nacional de Informações TóxicoFarmacológicas. Tabela 4. Casos Registrados de Intoxicação Humana, de Intoxicação Animal e de Solicitação de Informação por Agente Tóxico. Brasil, 2013b. Available from: http://sinitox.icict.fiocruz.br/sites/sinitox.icict .fiocruz.br/files//Tabela4_2013.pdf. Updated 2017 March 18.

Folz, S.D.; Kakuk, T.J.; Henke, C.L.; Rector, D.L.; Tesar, F.B. Clinical evaluation of amitraz as a treatment for canine demodicosis. Veterinary Parasitology, 16(3-4): 335-341, 1984.

Fonseca, Z.A.A.S.; Ferreira, C.G.T.; Ahid, S.M.M. Ectoparasitas de ruminantes na região Semiárida do Rio Grande do Norte, Brasil. Acta Veterinaria Brasilica, 3(4): 141-145, 2009.

Gunaratnam, P.; Wilkinson, G.T.; Seawright, A.A. A study of amitraz toxicity in cats. Australian Veterinary Journal, 60(9): 278-279, 1983.

Guo, H.; Zhang, P.; Wang, J.; Zheng, J. Determination of amitraz and its metabolites in whole blood using solid-phase extraction and liquid chromatography-tandem mass spectrometry. Journal of Chromatography B, 951-952: 89-95, 2014.

Hollingworth, R.M. Chemistry, biological activity, and uses of formamidines pesticides. Environmental Health Perspectives, 14:5769, 1976

Hugnet, C.; Buronrosse, F.; Pineau, X.; Cadore, J.L.; Lorgue, G.; Berny, P.J. Toxicity and kinetics of amitraz in dogs. American Journal of Veterinary Research, 57(10): 1506-1510, 1996.

Kizil, O. Balikçi, E.; Dabak, M.; Ozdemir, H. Amitraz intoxication in two cattle. Revue de Medicine Vétérinaire, 159(3):166-168, 2008.

Lim, J.H.; Kim, S.H.; Kim, K.H.; Park, N.H.; Shin, I.S.; Moon, C.; Park, S.H.; Kim, S.H.; Kim, J.C. Reproductive and developmental toxicity 
of amitraz in Sprague-Dawley rats.

Toxicology Research, 26(1): 67-74, 2010.

Marafon, C.M.; Delfim, C.I.G.; Valadao, C.A.A.; Menotti, R.; Andrade, S.F. Analysis of amitraz in cats by gas chromatography. Journal of Veterinary Pharmacology and Therapeutics, 33(4): 411-414, 2010.

Mueller, R.S. Treatment protocols for demodicosis: an evidence-based review. Veterinary Dermatology, 15: 75-89, 2004.

Mueller, R.S.; Bensignor, E.; Ferrer, L.; Holm, B.; Lemarie, S.; Paradis, M.; Shipstone, M.A. Treatment of demodicosis in dogs: 2011 clinical practice guidelines. Veterinary Dermatology, 23: 86-e21, 2012.

Oglesby, P.A.; Jouberta, K.E.; Meiringb, T. Canine renal necrosis and haemorrhage following ingestion of an amitraz-formulated insecticide dip. Journal of the South African Veterinary Association, 77(3): 160-163, 2006.

Omoja, V.U.; Asuzu, I.U.; Anika, S.M. Assessment of the hepatic and renal effects of sub-chronic administration of sub-lethal doses of amitraz/xylene in albino Wistar rats. Comparative Clinical Pathology, 25(1): 203-209, 2016a.

Omoja, V.U.; Anika, S.M.; Asuzu, I.U. The effects of sub-chronic administration of sub-lethal doses of amitraz/xylene on selected reproductive parameters of male Wistar rats.

Iranian Journal of Veterinary Research, 17(4): 277-280, 2016 b.

Omoja, V.U.; Anika, S.M.; Asuzu, I.U. Haematological changes in albino wister rats exposed to sub-chronic administration of sublethal doses of Zamitraz ${ }^{\circledR}(12.5 \%$ amitraz). Journal of Applied Animal Research, 45(1): 76-79, 2017.

Pierpoint, A.C.; Hapeman, C.J.; Torrents, A. Kinetics and Mechanism of Amitraz Hydrolysis. Journal of Agricultural and Food Chemistry's. 45(5): 1937-1939, 1997.

Proudfoot, A.T. Poisoning with amitraz. Toxicological Reviews, 22(2): 71-74, 2003.

PUBCHEM. Open Chemistry Database. Amitraz. Available <http://pubchem.ncbi.nlm.nih.gov/compound /amitraz\#section=Top>. Updated 2015 February 24.

Saito, T.; Yamamoto, R.; Inoue, S.; Kishiyama, I.; Miyazaki, S.; Nakamoto, A.; Nishida, M.; Namera, A.; Inokuchi, S. Simultaneous determination of amitraz and its metabolite in human serum by monolithic silica spin column extraction and liquid chromatography-mass spectrometry. Journal of Chromatography B, 867(1): 99-104, 2008.

Sakate, M.; Florio, J.C.; Palermo Neto, J. Efeitos tóxicos do praguicida amitraz: uma revisão. Comunicações Científicas da Faculdade de Medicina Veterinaria e Zootecnia da Universidade de São Paulo, 16(1-2): 45-51, 1992.

Santarém, V.A.; Andrade, S.F.; Albert, H. Endo e ectoparasiticidas. In: Andrade, S.F. Manual de terapêutica veterinária. 3. ed. São Paulo: Roca, 2008, p.520-560.

Sartor, I.F.; Santarém, V.A. Agentes empregados no controle dos ectoparasitos. In: Spinosa, H.S.; Górniak, S.L.; Bernardi, M.M. Farmacologia aplicada à medicina veterinária. 4. ed. Rio de Janeiro: Guanabara Koogan, 2006, p.480-492.

Smerdel, J.P.S.; Zamberlan, V.D.; Andrade, S.F. Estudo da reversão da intoxicação experimental por amitraz por via tópica em gatos com o uso da ioimbina. Colloquium Agrariae, 4(1): 15-22, 2008.

Xavier, F.G.; Maruo, V.M.; Spinosa, H.S. Toxicologia dos medicamentos. In: Spinosa, H.S.; Górniak, S.L.; Palermo-Neto, J. Toxicologia aplicada à medicina veterinária. 1. ed. Barueri: Manole, 2008, p.117-133.

Zanella, R.; Pavan, F.A.; Flores, E.M.M.; Martins, A.F. Determination of amitraz in cattle dipping baths by high-performance liquid chromatography. Journal of High Resolution Chromatography, 22(4): 247249, 1999. 